第13表 期別主要原単位

第14表 年間部門別電力消費原単位

第1図 操業系統図

\section{4. 結 言}

以上当所の現状につき略述したが，当所の 金銀製鍊 は，青化，比選(混永)，浮選と各種の方法を駆使して金 銀の回収につとめているが，総合実收率ではまだ満足す べき值が得られていない。とくに尾鉱の銀は他所に比し 実收率では劣らぬにしても，Ag 30g/t と高いのである
から浮選操業の検討改善によつて青化尾鉱中よりさらに 回収しうるのではないかと考えている。当面の諸問題と しては,

（1）浮選成績の向上

（2）シックナ，オリバー操業における粘土鉱対策

（3）青化実收率の向上と適正原単位

(4) 鈗涬の利用研究

があげられるが，いずれも早急に解決しなければならな い課題である。ここに諸賢のご教示を切に打願いする次 第である。

\title{
鯛生鉱業所の金銀青化製錬 \\ Cyanidation of Gold and Silver Ores at Taio Mine
}

\author{
正会員中 川喬 夫* \\ Takao NAKAGAWA
}

\section{1. 緒言}

位置・交通当鉱山の事業地は大分・福岡県にまた がり, 約 $4 \mathrm{~km}$ 余りで熊本県境に接している。交通は鹿 览島本線久留米駅または羽犬塚駅より鯛生までバスで 3 時間を要し, 久大線日田駅より鯛生までバスで 2 時間を 要する。

沿革 当鉱山の発見は明治 27 年 3 月と伝えられ，鯛 生の田島儀市, 鹿児島の南郷某外数名の共同出資により

明治31年 正式に採掘に着手, その後外人経営の末期頃 全泥青化法にて 200t/日

大正 15 年 $300 t /$ 日 に拡張, 部分的増補により昭和 7 年 まで $400 \mathrm{t} /$ 日

昭和 7 年 新しく隣接して $500 t /$ 日 製錬所増設

昭和 8 年 旧製錬所も $500 t /$ 日改造着手

昭和 9 年 1 月 $1,000 \mathrm{t} /$ 日 の設備完成（鯛生側）

昭和13年 3 月 $500 \mathrm{t} /$ 日処理の浮選, 青化併用製鉬法 により別個に新設着手，15力月を要して完成 (矢部側)

昭和14年 5 月：合計 $1,500 t /$ 日 の設備にて操業開始 昭和18年 金山整備令により保坑鉣山に指定され，帝国 鉱業開発株式会社㳊譲渡休山

昭和 31 年 4 月 住友金属鉱山株式会社，新鉱業開発株 式会社の共同出資により，鲖生鉱業株式会社 が設立され整備開発，水没坑道の排水に着手

昭和33年 4 月より珪酸鉱出鉱 (売鉱)

昭和35年 2 月 $250 \mathrm{t} /$ 日 の青化製錬場建設工事開始

* 鯛生釷業株式会社鯛生鈗業所製鏳課長
昭和35年 11 月 工事完成，引続き操業に入り $270 \mathrm{t} /$ 日 処理になり現在にいたる。

処理鉱石の性状鉣種は含金銀石英鉱, 鉱床 : 裂力 充填鉱床, 母岩: プロピライト, 脈石: 石英, 方解石, 比重は2.60，プライマリースライムは粗鉱中約 $9 \%$, 水 分平均 $4 \%$ 程度であり, サイアニサイドの含有量が少な く，取扱いは比較的容易である。鉱石中の金は大部分自 然金で，一部はパイライトの中に含まれている。金粒の 大きさは $20 \mu$ 以下である。銀は，ほとんど輝銀鉱の形で 含まれ，大きさ泣 $50 \mu$ 前後のものである。

従業員 製錬人員注課長以下 26 名, 内職員 4 名, 女 子 6 名で, 破哗 4 名，摩鉱 3 名，青化 3 名，精金 1 名, その他試験，事務，修理等になっている。運転番注係員 1 , 摩鉱 1 , 青化 1 で各直とも 3 名である。 鎕業所全従業員は 245 名である。

\section{2. 製鍊操業概要}

製錬法は全泥青化製錬法で，粗鉱品位およそ Au 5.0 $\mathrm{g} / \mathrm{t}, \mathrm{Ag} 20 \mathrm{~g} / \mathrm{t}$ の鈗石を $270 \mathrm{t} /$ 日処理し, $\mathrm{Au} 12.0 \%$, Ag 45\%の金銀殿物まで製鍊し，殿物は精金場にて精地 金としている。製鍊は破砕，摩鉱，青化の 3 つの過程に 大別される。

\section{$2 \cdot 1$ 破砕場}

坑内貯鉱舎より $8 \mathrm{t}$ 積ダンプトラックにて粗鉱舎 (容 量60 t ）まで運搬した粗鉱石は，エプロンフィーダでグ リズリに給鉱する。オーバーサイズはブレーキクラッシ +で1 次破砕し，グリズリのアンダーサイズとともに， ダブルデッキの 1 号エリプティックスクリーンでふるい 
分けを行なつている。網目は $14 \mathrm{~mm}$ であり, +14mmの 鉱石はコーンクラッシャに入る。-14mm 22 基の鉄製 鉱舎 ( 1 基容量 $200 \mathrm{t}$ ) に送られる。コーンクラッシャに て破砕された鉱石は, シングルデッキの 2 号エリプテッ クスクリーン（網目 13mm）でふるい分け，オーバーサ イズはコーンクラッシャへ繰返す閉回路 2 次破砕を行な つてー13mmは 1 号スクリーンの $-14 \mathrm{~mm}$ とともに摩鉱 鉱舎に送られる。

\section{2 摩鉱場}

摩鉱原鉱（サイズー $10 \mathrm{~mm} 80 \%$ 程度）はポイドメータ 一で科量後, マーシーグレートボールミルで青化液およ び石灰乳の適量とともに水分 $35 \%$ 程度で 1 次摩鉣および 金, 銀溶解がなされる。排泥はドル分級機で分級され, 分級機縊流は -200 mesh $45 \%$ 程度になつて 2 次摩鉱系 のバウル分級機に送られる。

バウル分級機はコニカルボールミルと閉回路をなしコ ニカルミル排泥はスラリーポンプでバウル分級機に繰返 される。バウル分級機溢流は - $200 \mathrm{mesh}$ 約 90\% となっ てワーマンポンプで青化場へ送られる。

\section{$2 \cdot 3$ 青化場}

バウル分級機の溢流はドルシックナ（ 2 基）に流入濃 縮される。濃縮されたスピゴットはドルコダイヤフラム ポンプで揚泥してコンディショナに入る。コンディショ ナで青化石灰，硝酸鉛を添加されてアジテータ（3. 基） 亿流入し, 最終薬品濃度 F. $\mathrm{NaCN} 0.07 \%, \mathrm{CaO} 0.03$ \%程度で約48時間攂挥して金, 銀の溶解を完了させる。

アジテータで攪拌を終えた鉱泥は1 次オリバーフイル 夕 (2 基) で沪過洗浄し，ケークは廃液でリパルプし, さらに 2 次オリバーフイルタ（2 基）で沪過洗浄を完了 する。2 次オリバーフイルタのケーク（鉱㳯）はベルト コンベヤで堆積場に送られる。

ドルシックナの溢流拉よび1次オリバーフィルタの沪 液はクラリファイヤに導いて沪過清澄を行ない液量を測 定し,クロ一真空塔にて金液の脱酸を行なつた後, 覀鉛 末を加えて，メリルプレスに圧送し，金・銀殿物を沪過 する。

廃液の一部はオリバーフィルタのケーク洗浄ならびに リパルピングに用い，余つた液は 2 次オリバーフィルタ の汇液とともに原液槽に送られ，マーシーミルおよびב ニカルミルの使用原液として反覆使用される。金・銀の 殿物は圧縮空気で脱水した後, 精金場に送られる。

\section{4 精金場}

青化工場を経て得られた殿物はAu $12.0 \%, \mathrm{Ag} 45 \%$ 前後を含有する。これを乾燥した後, 喼砂, 曹達灰, 珪 砂等の溶剂を配合し，熔解炉にて熔解してカラミを分離 した後, Au 21\%, Ag 76\% 程度の精地金として別子へ 送る。溶解カラミ中にはなお $\mathrm{Au} 270 \mathrm{~g} / \mathrm{t}, \mathrm{Ag} 2,100 \mathrm{~g} / \mathrm{t}$
程度を含有しているので，これを四阪島製錬所へ送つて いる。

\section{5 分析場}

分析場では一般鉱業分析を実施している。

\section{3. 主 要 設 備}

設備能力. $6,750 \mathrm{t} /$ 月, 工場総面積 $2,223 \mathrm{~m}^{2}$

据付動力 $1,173 \mathrm{PP}(868.7 \mathrm{~kW})$

工場構造 鉄骨造平家建スレート莫き

工場高さ $34 \mathrm{~m}$, 勾配 $30^{\circ} \sim 24^{\circ}$

\section{4. 操 業 成 績}

昭和 42 年 1 年間の処理量は 76, $914 \mathrm{t}$, 品位 $\mathrm{Au} 5.0 \mathrm{~g} /$ $\mathrm{t}, \mathrm{Ag} 18 \mathrm{~g} / \mathrm{t}$ で尾鉱品位は Au $0.12 \mathrm{~g} / \mathrm{t}, \mathrm{Ag} 2.4 \mathrm{~g} / \mathrm{t}$ で，実収率は $\mathrm{Au} 97.6 \%, \mathrm{Ag} 89.0 \%$ である。殿物は 3 $\mathrm{t}$ で品位 $\mathrm{Au} 12.53 \%, \mathrm{Ag} 43.05 \%$ である。

主要原単位は $90 \mathrm{~mm}$ ボール $0.89 \mathrm{~kg} / \mathrm{t}$ $50 \mathrm{~mm}$ ボール $0.86 \mathrm{~kg} / \mathrm{t}$ 青化石灰 $0.76 \mathrm{~kg} / \mathrm{t}$ 消 石灰 $4.97 \mathrm{~kg} / \mathrm{t}$ 硝 酸 鉛 $0.08 \mathrm{~kg} / \mathrm{t}$ 亜 鉛末 $0.10 \mathrm{~kg} / \mathrm{t}$ Fd 粗鉱舍

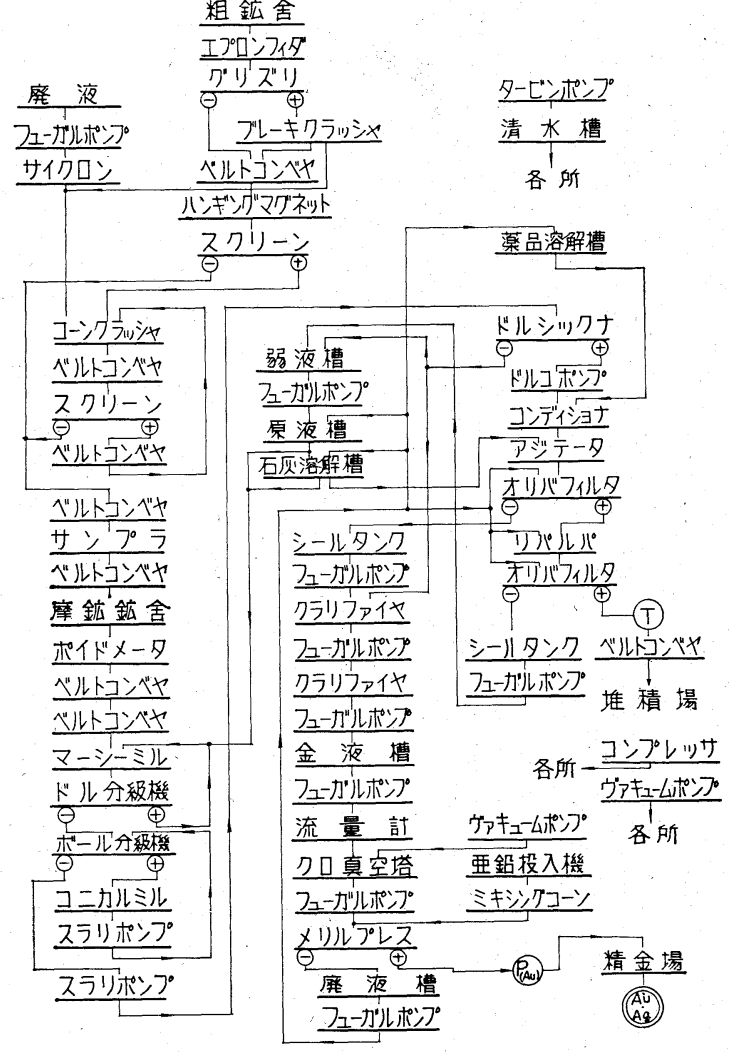

第 1 図 鯛生青化製錬工場系統図（42年8月） 


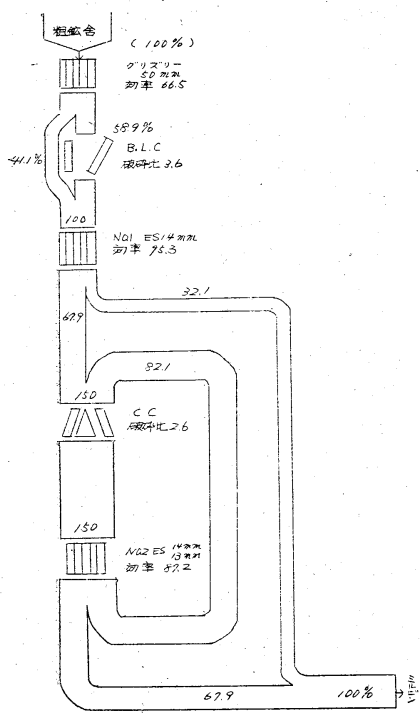

第 2 図破砕鉱石平衡図

電力使用量 $43.03 \mathrm{kWh} / \mathrm{t}$

工 数 $0.090 工 / \mathrm{t}$

である。薬品濃度は

シックナ溢流 $\mathrm{NaCN} 0.055 \%$

$\mathrm{CaO} \quad 0.039$

アジテータ排泥 $\mathrm{NaCN} 0.069$

$\mathrm{CaO} 0.035$

金

液 $\mathrm{NaCN} 0.059$

$\mathrm{CaO} \quad 0.035$

以上が 42 年 1 年間の実績である。

\section{5. 操業系統図および物量バランス}

（第 1 図，第 2 図，第 3 図，第 4 図参照）

\section{6. 最近の技術，または設備の進歩}

特に記するほどのものはないが，破砕場では粘土鉱処 理について水洗処理を行ない能率アップを行なつた。

水洗液は青化廃液を使用し，1号スクリーンでポンプ にてシャワーで水洗し，オーバーサイズは，コーンクラ ッシャの通常の回路に入り，アンダーはエーキンス分級 機にて分級される。エーキンス分流機溢流は，摩鉱バウ ル分級機に送られ，アンダーサイズは，通常の鉱石とと もに摩鉱鉱舎に送られる。これは粘土鉱のときのみ切替 えるよらに設置してある。粘土鉱処理で著しく手間取つ ていたが，ほぼ解決した。

なおエプロンフィーダの速度表示，操作ハンドルの引 出しによる操作の改良, ハンギングマグネットの新設, サイクロン式集塵ファンの設置替, コーンクラッシャ油 温上昇時警報，同オイルポンプ停止時の信号コーンクラ

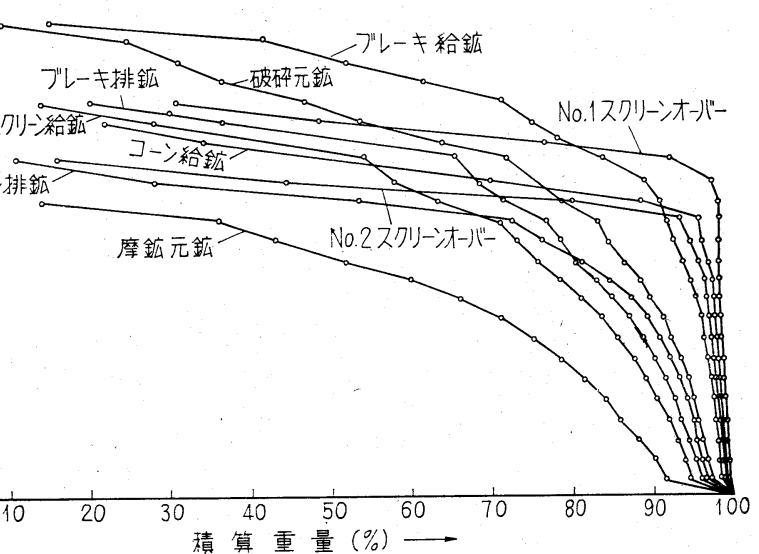

第 3 図 破砕鉱石粒度分布表

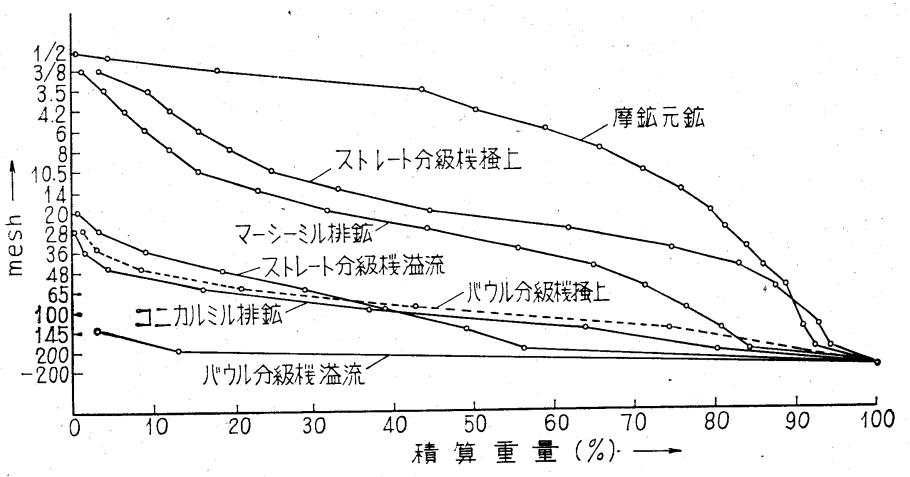

第4 図 摩鉣粒度分布図 ッシャと給鉱までのベルトコンベヤ，スクリーン等と連 動操作によるコーンクラッシャの過負荷防止等を行なつ ている。

摩釷場では，摩鉱鉱舎にバイブレータの取付, ポイド メータからマーシーミルまでベルトコンベヤ( 2 基 $)$ で送 つていたが，これを直接流送してコンベヤを廃止し，電 力節約を行なつた。ミルライナはマーシーボールミル， コニカルボールミルとも溝型ライナーに切替, ライナー の使用期間を平均 3 カ月程度延長した。またライナーボ 一トの再生使用，麻ワッシャを布ワッシャへと変え使用 している。摩鉱場より青化場へスラリーポンプにて送つ ていたが，故障や摩減が多く，この保持費が 著しく多 く，42年ワーマンポンプに切替えて回転速度調整後は， 修理，摩耗による部品取替等が少なく，経費節減に役立 つている。最近では摩鉱原液になる使用液のパイプを増 設し使用液を増し分級機の効率を高め, - 200 mesh $90 \%$ を保ち，処理鉱量を増すべく研究操作中である。青化場 では，アジテータのサイドェアーリフトを各槽 4 本計 12 本に増加し（39年）溶解率の向上を計つた。コンデイシ ョナからアジテーターの給泥パイプの付替によるショー トサアキットの解消, 各アジテータ排泥パイプの位置上 げによる溶解時間の延長，同ラウンダに自動掃除器を取 
付け溶解率の向上および保安上危険性の解消, またアジ テータ側壁の居付が溶解時間に著しく影響するところか ら, 自動居付防止器の取付を行なっている。金液沪過を 2 段沪過とし殿物揚回数の減, 殿物品位の向上による精 金費の減等の改良を行なつた。クラリファイヤの沪布は 化繊を試験使用中で結果は大体良好のようである。

使用薬品の硝酸鉛は, 40 年から鉛と硝酸を購入し, 自 家製造して使用しているが，酸化鉛使用時とすれば，経 費的に節約になつている。なお各所パイプの堌改設等行 なつているが, パイプ内の居付, 腐蝕が今後の問題とし て残る。同じくタンク座張等の腐蝕対策も, 今後整備し ていかなければならない問題である。
なお， 42 年 3 月から青化当番各直 2 名を 1 名にし，製 鍊内の修理班をつくり, 保安施設その他の修理改善に当 つている。青化当番の 1 名への減は, 各機器の整備它徹 底し故障を少なくし，できるだけ人手のいらないょうに 自動化を進めた結果で, 1名とした現在支障は全然なく， むしろ能率は向上している。

\section{7. 結言}

昭和35年の操業当初は $250 t /$ 日の処理鉱量であつたが その後破砕場で粘土鉱の水洗処理, 細砕化に努めた結 果, 摩鉱の処理鉱量は270t/日まで増加しさらに $290 \mathrm{t} /$ 日 処理を目標㯰いて，コストの切下に努力している。

\section{大口鉱業所における金銀青化製鍊}

\section{Cyanidation of Gold and Silver Ores at Oukuchi Mine}

正会員永 田 $\begin{gathered}\text { 虎 } \\ \text { Torao NAGATA }\end{gathered}$

\section{1. 緒言}

大口鉱山は鹿児島県大口市にあり，北薩の中心大口盈 地の東北に所在し, 稼行も明治初年からと伝えられてい る。開山以来本山地区鉱床のみ稼行されてきたが年々金 品位低下の傾向著しく，これに対処しか叔て探鉱中の南 西約 $2 \mathrm{~km}$ 付近（下牛尾地区）で昭和 42 年上期高品位の 新鉱床開発され今なお開発続行中で稼行の主力は新鉱床 に移行され鉱況大きく変換しつつある。この両地区の鉱 石は性状を異にし，新鉱床鉱石は極好硬く，かつ金粒 は検鏡困難な極微粒金のため，製鍊においては粗砕場を 改造し(昭和42年末完了)さらに現在細摩対策中である。

現在の従業員数は第 1 表のよらである。

第1表 従業員”数

\begin{tabular}{|c|c|c|c|c|c|c|c|c|c|c|}
\hline & 採鉣 & 調査 & 製錬 & 分析 & 工作 & 総務 & 経理 & 保安䀢 & 鈤 & 合計 \\
\hline $\begin{array}{l}\text { 職員員墉 } \\
\text { 臨時 } \\
\text { 計 }\end{array}$ & $\begin{array}{r}7 \\
66 \\
4 \\
77\end{array}$ & $\begin{array}{r}3 \\
11 \\
1 \\
15\end{array}$ & $\begin{array}{r}3 \\
18 \\
21\end{array}$ & $\begin{array}{l}1 \\
2 \\
1 \\
4\end{array}$ & $\begin{array}{r}4 \\
29 \\
1 \\
34\end{array}$ & $\begin{array}{r}3 \\
6 \\
5 \\
14\end{array}$ & $\begin{array}{l}1 \\
7 \\
1 \\
9\end{array}$ & \begin{tabular}{c|c}
1 & 3 \\
7 & 0 \\
1 & 0 \\
9 & 3
\end{tabular} & \begin{tabular}{r|}
1 \\
0 \\
1
\end{tabular} & $\begin{array}{r}26 \\
139 \\
13 \\
178\end{array}$ \\
\hline
\end{tabular}

なお青化難溶の含金硫化物を比選により除去売鉱して いる外，鉱石は珪酸分が極めて高いので含金珄酸鉱とし て一部鉱石のまま売鉣している。最近の生産量は第 2 表 のとおりである。

\section{2. 処理鉱石の概要}

本山地区鉱床群の稼行は極度の品位低下により全面休

\footnotetext{
* 鯛生鉱業株式会社大口鉣業所製錬課長
}

$860\langle 186\rangle$
止され, 昭和 42 年上期以来下牛尾地区の新鉱床のみの採 掘に移行され，ここに大変換となつた。この両者の鉱石 は頗る性状を異にしている。本山地区鉱石は永年種々検 查研究されてきているが, 新鉱床の下牛尾地区鉱石の金 粒は極めて微粒で顕微鏡観察も極めて困難で，わずかに 現在「エレクトロンマイクロプルーブX線アナライザー」

第 2 表 珪酸鉱生産量

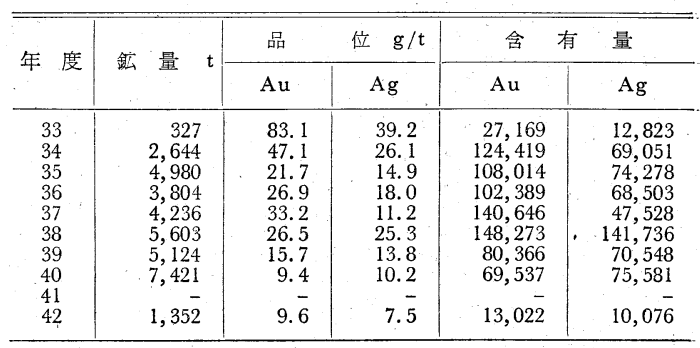

第 3 表 大口鈗石完全分析一例（昭和42年 9 月20日分析）

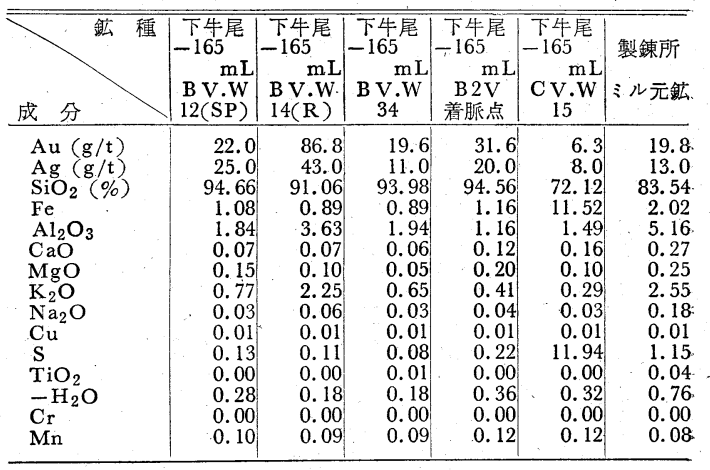

